\title{
小児の慢性顎骨骨髄炎に関する病理学的検討
}

\author{
福田容子・戸塚盛雄・武田泰典*・工藤啓吾**
}

及川理***

\section{Pathological analysis for chronic osteomyelitis of the jaws in childhood}

\author{
Yohko Fukuta - Morio Totsuka - Yasunori Takeda* \\ Keigo Kudo** • Osamu OiKawA***
}

\begin{abstract}
Pathological analysis of 4 cases (three males and one female) of chronic osteomyelitis of the jaw's in childhood was performed.

In case 1 of a 12 -year-old male, histopathological finding of maxillary lesion showed typical chronic suppurative osteomyelitis in early stage, but became similar to finding of ossifying fibroma in latter stage. Case 2 of a 9-year-old male and case 3 of a 12-year-old female were diagnosed as chronic diffuse sclerosing osteomyelitis in the mandible. Case 4 of a 15 -year-old male revealed a finding of Garré's osteomyelitis in the mandible.

Since histopathologic findings of chronic osteomyelitis in childhood were composed of various patterns of osteomyelitis, the detailed clinical coursear and histopathological examinations in numerous areas were important for final diagnosis and treatment.
\end{abstract}

Key words: chronic ostesmyelitis, jaw, childhood

岩手医科大学碀学部暗科予診室

（主任：戸塚盛雄教授）

* 岩手医科大学菌学部口舼病理学諈坐 （主任：鉿木鍾美教授）

**岩手医科大学桏学部口腔外科学第 1 蓝座 （主任：藤岡幸堆教授）

*** 岩手医科大学㳡学部口腔外科学第 2 諳匧 (主任：関山三郎教授）

Department of Oral Diagnosis, School of Dentistry, Iwate Medical University (Chief: Prof. Morio Totsuka)

* Department of Oral Pathology, School of Dentistry, Iwate Medical University (Chief: Prof. Atsumi Suzuki)

** Department of Oral \& Maxillofacial Surgery I, School of Dentistry, Iwate Medical University (Chief: Prof. Yukio Fujioka)

*** Department of Oral \& Maxillofacial Surgery II, School of Dentistry, Iwate Medical University (Chief : Prof. Saburo Sekiyama) 受付日：昭和61年 9 月 8 日
顎骨骨髄炎は，必ずしも定型的な臨床扰よび病理組織 所見を呈するとは限らず，ときには従来の買骨骨檤炎の 分類 ${ }^{1,2)}$ に該当しない症例が存在することがある．特に 小児の場合，顎骨骨䯣炎はまれであり，また代謝，細胞 增殖能が昰盛であるため，顎骨の fibro-osseous lesion （特に化骨性線維腫，線維性骨暴形成症）との鑑別か臨 本的にも病理学的にも問題となってくる.

今回は，まれな小児の慢性顎骨骨髄炎について，䫑骨 の fibro-osseous lesion との鑑別点を中心に検討を加え たので報告する.

\section{材 料と方 法}

倹索に用いた材料は, 本学口腔病理学講座において取 り扱った生檢および手術材料のらち，小児の慢性買骨骨 髄炎 4 例（男児 3 例，女児 1 例）である。検体は通法飞 従い, パラフィンまたはセロイジン切片とし， H-E 染 色をほどこし，これらの病理組織所見と臨床所見とを比 較众討した。 
表 1 臨床所見

\begin{tabular}{|c|c|c|c|c|c|c|c|}
\hline 症例 & 性・ & 年齢 & 経 過 & 部 位 & 臨床症状 & X線所見 & 臨床㡎断 \\
\hline 1 & 男 & 12 & 6 年 & $\underline{6 \sim 1}$ & 腫 脹 & スリガラス様不透過像 & 線維性骨異形成症 \\
\hline 2 & 男 & 9 & 1.5か月 & $\mid \overline{\mathrm{E}} \sim$ 左下顎枝 & $\begin{array}{l}\text { 腫 脹 } \\
\text { 圧 痛 }\end{array}$ & $\begin{array}{l}\text { 不規則な骨吸収像中に } \\
\text { 不透過像が散在 }\end{array}$ & 下顎骨骨髄炎 \\
\hline 3 & 女 & 12 & 4 年 & $\overline{2} \mid \sim$ 左下顎枝 & $\begin{array}{c}\text { 腫 脹 } \\
\text { 自発痛(間歇性) }\end{array}$ & 虫食い䇐像 & 下顎骨骨髄炎 \\
\hline 4 & 男 & 15 & 3 か月 & $\overline{7 \sim 4}$ & 腫 脹 & スリガラス様不透過像 & 骨腫瘍 \\
\hline
\end{tabular}

結

果

症例の臨床所見の概要は，表１に示すと和りである.

症例 1: 12歳 男.

\section{1. 臨床所見および経過}

$5 \sim 6$ 歳時に右頓部腫脹にて歯科を受䛦したが，X線 検査の結果，異常なしと診断された。7 歳時, 某公立病 院にて右側上顎臼歯部腫脹のため手術を受けたが, 症状 は軽快しなかった。この時の診断名は不明であった。

9 歳時に右上顎臼歯部の腫脹を主訴に本学口腔外科を 受診した。初診時, 右頓部にび漫性の無痛性腫脹が認め られた。只腔内では, 右上顎乳犬歯部より第 1 大臼歯部 煩側歯肉に 無痛性, 骨様硬のび漫性の腫脹が認められ た、腫脹部分に含まれる歯はすべて生活歯であった，X 線的に腫脹部は一様にスリガラス様不透過像を呈してい た (写真 1)。線維性骨異形成症の 臨床診断のもとに 9 歳時 2 回, 10 歳時と 12 歳時の計 4 回, 膨隆部の骨削除が 施行された。 なお，抗生物質は奏効しなかった。

\section{2. 病理組織所見}

9 歳時の初回の手術材料では, 顎骨骨髄の骨梁は破壞 され，大きな膿瘍か゚形成されるとともに，細菌集塊も散 見された，膿瘍周辺の骨骨迶は好中球をはじめとした炎症 性細胞浸潤を伴う疎な線維性結合組織よりなり，浮腫性 の変化も認められた（写真 $2 \mathbf{A}$ )。 また，一部では既存 の骨に不規則に新生骨が添加し，骨硬化像を呈する部分 もみられた（写真 2 B )。以上より, 病理組織診断は慢 性化膿性骨髄炎とした。これより 2 か月後の手術材料で は，既存の骨梁に新生骨の添加か゚あり，それらは不規則 な改造線により接して扣り，モザイク様構造を呈してい た。骨䯣は細胞成分に富む線維性結合組織よりなり，ご く軽度の炎症性細胞浸潤が認められた（写真 $2 \mathbf{C}$ ). 12 歳時の手術材料では層板骨あるいは線維骨が梁状に活発 に増生しており, 骨梁周囲には骨芽細胞の配列がみられ た。骨梁間は細胞成分に富む密な線維性結合組織よりな り，炎症性細胞浸潤はほとんと゚認められなかった（写真 2 D). また，骨膜に近い部では，層板骨梁が多層性に 骨膜と平行に配列している像が認められた。

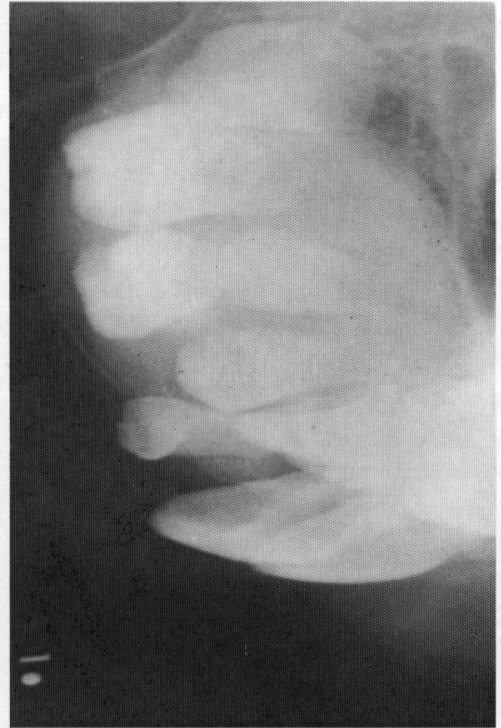

写真 1 症例 1 . 咬合法写真. 6〜1 部に境界不明瞭なスリガラス様不透過像がみ られる。

\section{症例 2:9 歳 男.}

\section{1. 臨床所見および経過}

1 か月半前に左顎角部に出脹が出現し, その後徐々に 増大したため本学口腔外科を受診した。腔内所見で は, 左下顎第 2 乳臼歯, 第 1 大臼歯部の歯肉頓移行部か ら下顎枝にかけて骨様硬の腫脹と圧痛和よび開口痛が認 められた。 蝕, 歯の動摇, 排膿などはなかった。 $\mathrm{X}$ 線 検査では，左下顎第 2 大臼歯部より下顎枝ならびに筋突 起部にかけて 境界不明瞭な骨の破壊・吸収像が認めら れ，その中に不透過巣が散在してみられた（写真了）. 顎骨骨髄炎の臨床診断のもとに抗生物質の投与がなされ たが奏効せず，化骨性線維腫も考えられた。左下顎第 2 大曰歯歯胚を含め，病変部の搔爬を行った。

\section{2. 病理組織所見}

一部に肉芽組織がみられ，その周囲は活発な線維骨の 新生を伴ら線維性結合組織よりなっていた(写真 $4 \mathbf{A})$. 
Jan. 1987

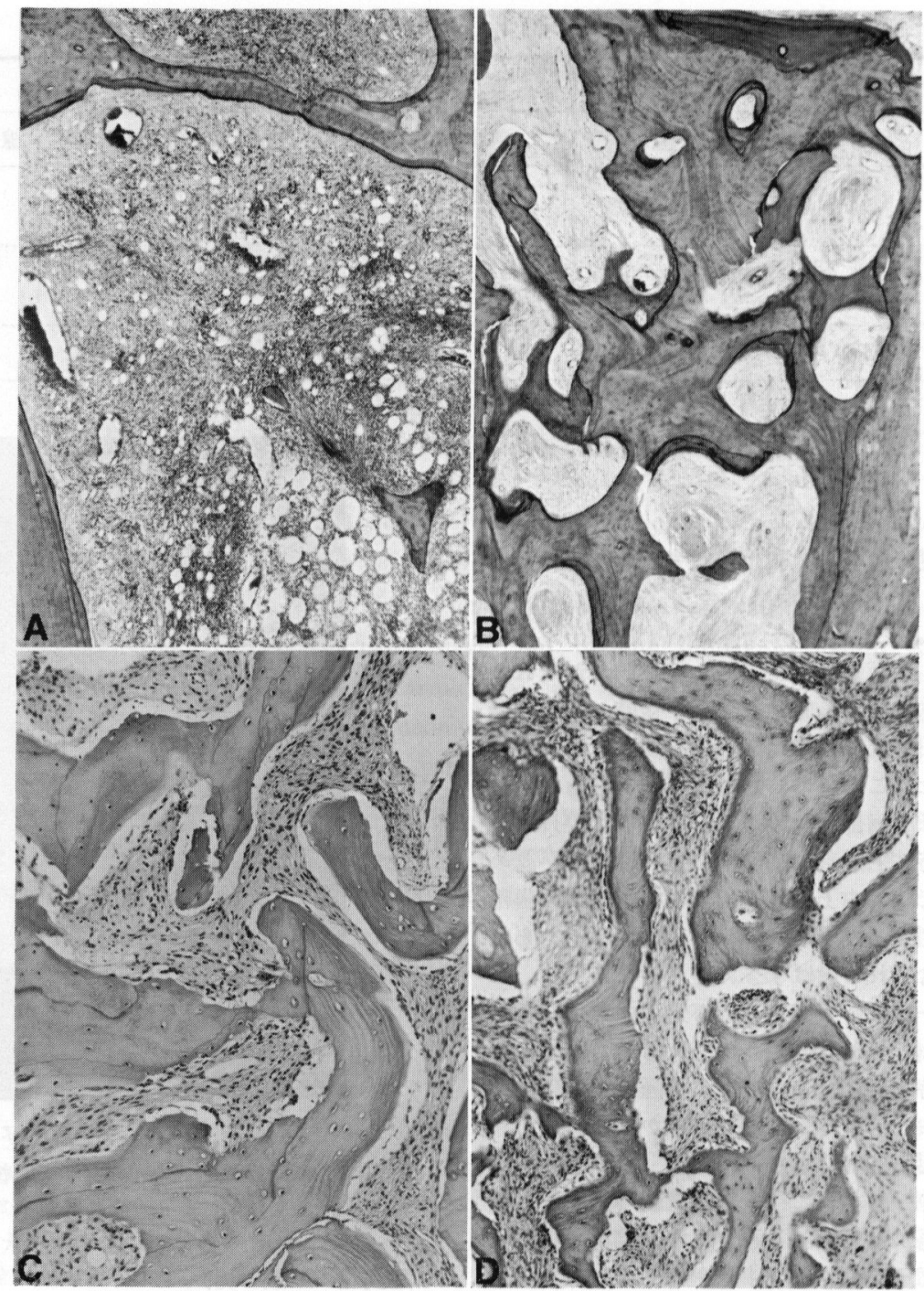

写真 2 症例 1 .

A. 初回手術時の組織像。骨骾の好中球を伴 5 炎症性細胞浸潤。(H-E 染色, $\times 60$ )

B. 初回手術時の組織像. 既存の骨梁のモザイク様構造と骨䯣の線維化。(H-E 染色, × 60 )

C. 2 か月後（9歳）の組織像。骨梁はモザイク様構造を呈し，骨梁間は軽度のび漫性炎症性細胞 浸潤を伴 弓，細胞成分に富む線維性結合組織よりなる。(H-E 染色，×150)

D. 12歳時の組織像。多量の骨新生をみる。骨梁間は細胞成分に富み, 炎症性細胞浸潤はほとんと みられない。（H-E 染色， ×150）

また，他部位では 既存の骨梁に 新生骨の 添加がみられ た。骨梁間は柾な線維性結合組織よりなり，び漫性の炎 症性細胞浸潤が認められた（写真 4 B ).

症例 3:12歳 女.

\section{1. 臨床所見および経過}

8 歳時に左下顎第 2 乳臼歯部の根尖性雨周炎による疼 痛のため，某開業医にて同歯の抜歯を受けたが，その後
も同部の疼痛, 腫脹が持続した。薬剂服用により疼痛は 軽減したが，腫脹は消退しなかった。その後，間歇的に 左頓部の有痛性の腫脹が出現し，9歳時に本学口腔外科 を受診した。 X線検查にて，左下顎第 1 小眠歯部より第 1 大臼歯部にかけて顎骨骨体部に虫くい様の透過像を呈 していた。下顎骨骨䯣炎の臨床診断のもとに左下顎第 1 小四歯抜歯，第 2 小曰歯歯胚搔爬，同部腐骨除去を施行 


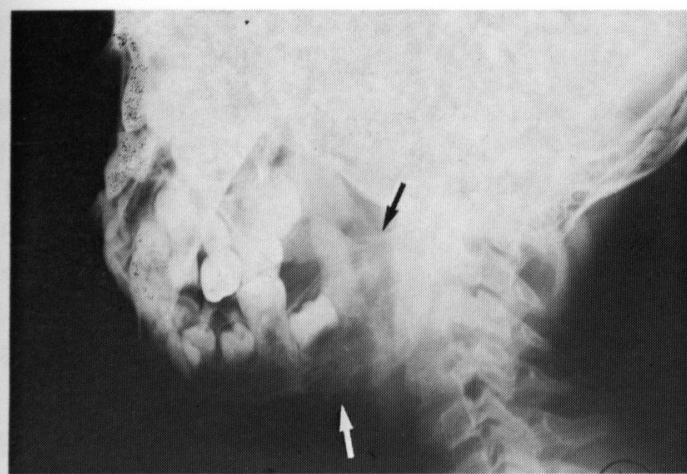

写真 3 症例 2 .

下顎骨斜位法写真. $\mid \overline{7}$ 部から下䭭枝にかけて不規 則な骨の破壊・吸収像とその中の不透過像の混在。

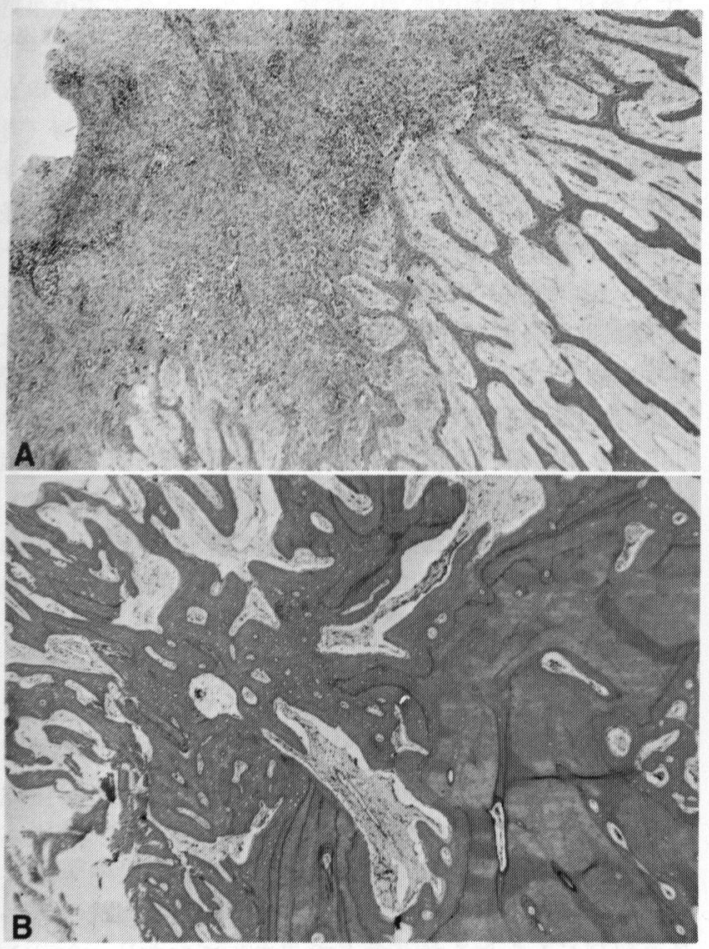

写真 4 症例 2 . 病理組織像.

A. 炎症性肉芽組織とその周囲の新生骨梁。(H-E 染色, $\times 56$ )

B. 骨硬化像。骨梁間はび漫性炎症性細胞浸潤を伴 弓疎な線維性結合組織よりなる。(H-E 染色, $\times 56$ )

した。細菌検查では $\alpha$-ブドウ球菌が検出されたが，抗生 物質は奏効しなかった。ささら 4 か月後に左下顎第 1 大 臼歯抜歯，第 2 大臼歯歯肧怪爬，腐骨除去を施行 した が，感冒罹患時に左下顎部の有痛性腫脹があった。12歳

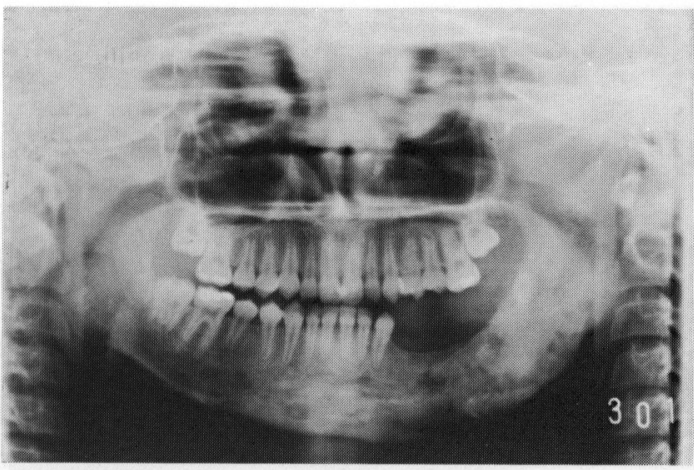

写真 5 症例 3. ハ八ノラマ $\mathrm{X}$ 線写真. $\overline{2 \sim 8}$ 部から左 下顎枝に及ぶ虫くい様像がみられる。

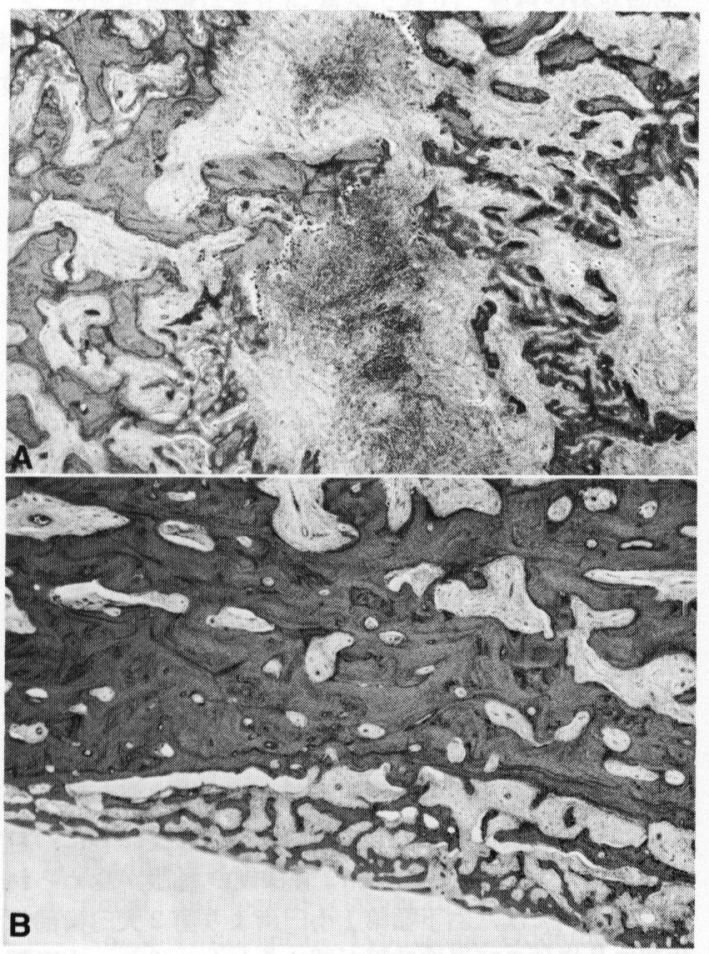

写真 6 症例 3 . 病理組織像.

A. 體瘍の形成とその周辺の骨破壞と骨新生像の混 在，骨䯣の好中球を含を炎症性細胞浸潤を伴 5 線維化をみる。(H-E 染色, × 28)

B. 皮質骨周囲の著明な骨硬化像。骨膜下の骨新生 像も同時にみられる。(H-E 染色，×28）

時， decorticationを施行したが効果なく，X線検查で左 下顎中切歯部から左下顎智歯部に及ぶ骨体部と，下䫇枝 にまで及ぶ虫くい様透過像が認められるにいたった（写 真 5)。ささらに，顔面の著しい非対称をきたすよらにな ったため，右下顎犬歯部より左下顎智歯部に及ぶ骨体部 


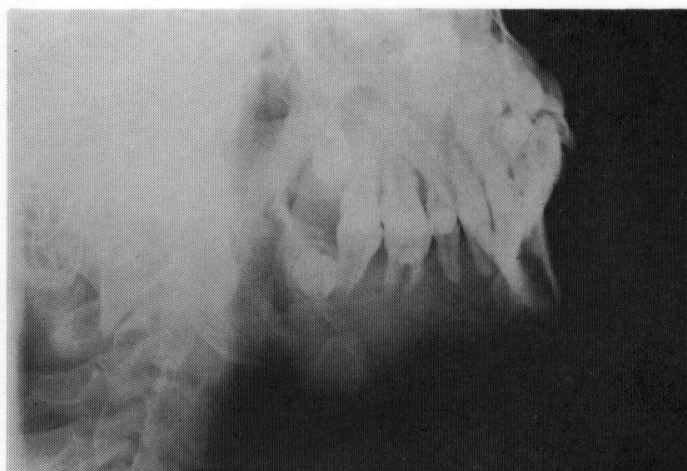

写真 7 症例 4 . 下顎骨斜位法写真. $\overline{7 \sim 4}$ 部の境 界不明暸なスリガラス様不透過像.

と左筋突起を含も下顎枝を連続離断し，金属プレートと 腸骨海綿骨骨髄移植にて再建を行った。

\section{2. 病理組織所見}

下顎骨の連続離断手術材料は，全体的に膨隆してい た。組織学的には, 病変部のほぼ全域に小膿瘍が散在し て認められ，膿瘍に接する既存の骨梁には多数の破骨細 胞による骨吸収が認められた。また，同時に小膿瘍周囲 に多数の線維骨の新生があり,これらの周囲には骨芽細 胞の不規則な配列がみられた，骨骾組織はすべて好中球 を主とした炎症性細胞浸潤を伴う線維性結合組織により 置換されていた（写真 $6 \mathbf{A}$ ）。また一方では，既存の層 板骨梁は肥厚し，著明な硬化像を呈する部分もみられ た。皮質骨の外側には骨膜性の化骨が認められた。すな わち，細い骨梁が既存の皮質骨に接して網目状に形成さ れており，骨梁間は疎な線維性結合組織より成っていた (写真 6 B ).

症例 $4: 15$ 歳 男.

\section{1. 臨床所見および経過}

約 1 週間ほど前に右下顎臼歯部の疼痛を自覚, 同時に 同部顎骨の腫脹にも気つきき本学口腔外科を受診した。ロ 腔外所見では，右側顎角部に骨様硬の腫脹が認められ た。腔内では，右下顎第 1 小臼歯より第 2 大臼歯部骨 体部に骨様硬のび漫性腫脹が認められた。 また，右下顎 第 1 小臼歯から第 2 大臼歯まではすべて生活歯であっ た、X線検査により，右下顎第 1 小臼歯部から第 2 大且 歯部骨体部に境界不明暸なスリガラス様不透過像が認め られた（写真７）、下顎骨腫瘍の疑いにて生検が施行さ れ，骨髄炎の䛦断の下に decortication が施行された。 術後の経過は良好で再発の徴候はなかった。

\section{2. 病理組織所見}

層板骨よりなる比較的太い骨梁が，多層性に骨膜と平 行に配列している像が認められた。一部の骨梁には不規 則な改造線がみられた。骨梁周囲には骨芽細胞の配列が みられたが，ところにより破骨細胞が少数散見された。

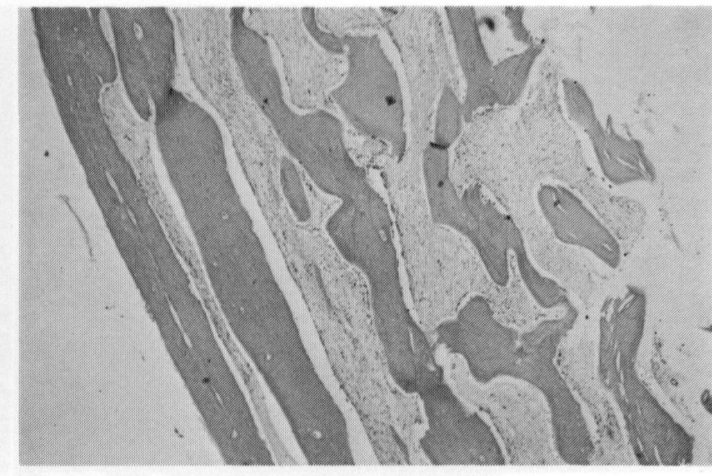

写真 8 症例 4 . 病理組織像。多層性に骨膜と平行 に配列する層板骨梁。骨梁間の線維性結合 組織には軽度の炎症性細胞浸潤がみられ る. (H-E 染色, $\times 28)$

骨梁間は疎な線維性結合組織より成り，ごく軽度のび漫 性の小円形細胞浸潤が認められた（写真 8 ).

\section{考察}

一般に小児の顎骨骨髄炎は，急性骨髄炎3) あるいは Garré 氏骨髄炎 ${ }^{4 \sim 8)}$ としての報告が多い，しかし，小昌 期の顎骨の慢性び漫性骨髄炎は非常に稀で，少数の報告 をみるにすぎない4，

症例 1 は, 長期の経過をとった症例で, 材料の採取時 期により組織像の推移か゚みられた。初期の病理組織所見 は，骨破壊と膿瘍形成が認められ，慢性化膿性骨髄炎の 像を呈していた，2回目の手術材料では炎症性変化は軽 度であったが，骨䯣炎に特徵的な，骨梁に吸収と添加を くり返したモザイク様構造が認められた。 $3 ， 4$ 回目の 手術材料では，炎症性変化はほとんど認められず，活発 な骨新生像を呈していた。したがって，後半の手術材料 のみでは顎骨の fibro-osseous lesion との鑑別が問題と なってくる. 活発な骨新生像は化骨性線維腫に類似して いるが，病変部の境界が非常に不明瞭である点が異なっ ていた7)、また，線維性骨異形成症とは，多量の層板骨 の形成，多数の骨芽細胞の配列，一部に同心円状の層板 骨の配列がみられるなどの点で異なっていた7). 今回は 全経過を通して観察できたので組織像の推移を理解でき たが, 経過途中の検体のみでは顎骨の fibro-osseous lesion と混同されやすいものと思われた。

症例 2 は, X線的に透過像が主体をなしており，その 中に不透過像が散見された。組織学的には炎症性肉芽組 織と骨新生像を呈する部と硬化像を呈する部の混在であ り，X線所見と一致していた。

症例 3 は，長期の経過をとった難治性の症例であっ た、X線的には広範な虫くい様透過像を呈し，組織学的 には症例 2 と類似していた。多くの小膿瘍の形成と, そ 
の周四の骨破壊と骨新生の混在像，既存の骨組織の著明 な硬化像が特徵的であった。 また同時に Garré 氏骨䯣 炎と同様の骨膜反応も呈していた。浅田 ${ }^{8)}$ は，び漫性硬 化性顎骨骨髄炎をX線的に，不透過像の增大を主とする I 型, 不透過像増強部に種々の程度の透過像の混在がみ られる II 型に分類している。 そして， II 型は青年層に多 く，病変が広範囲で，腐骨分離像は認められないとして いる，筆者らの症例 2 および 3 は，浅田の II 型に相当す るものと思われた。

症例 4 は，骨膜反応が主体をなしていた，Garré 氏骨 髄炎は骨膜による化骨が既存の皮質と垂直方向に配列す

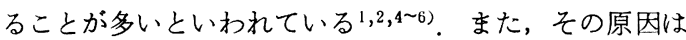
ほとんどが下顎大曰歯よりの感染か，あるいは他部位の 炎症栄の影響といわれている。症例 4 は原因となる は存在せず,他の原因もみあたらなかった。しかし，骨膜 反応が主であることと，骨梁の配列が多層性で骨膜と平 行であることより，他の顎骨の fibro-osseous lesion の

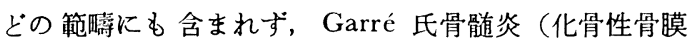
炎）に相当するものではないかと推察された。 また，化 骨性骨膜炎は単独で存在するばかりではなく，種々の疾 患と合併してみられることがある ${ }^{6)}$ ，特に若年者の靧骨 では Ewing 肉腫と合併してみられることがあるので注 意を要する。 また，症例 $1 ， 3$ にも化骨性骨膜炎の合併 がみられた。 Rowe $\mathrm{e}^{4)}$ す小児期の顎骨骨髄炎で化骨性骨 膜炎を伴ったものを報告している．このことは，小児は 生体の反応が旺盛であるため，顎骨の炎症による骨膜反 応が生じやすいことによると思われる。

䫇骨骨髄炎は，臨床的ならびに病理組織学的に fibroosseous lesion と鑑別を要する場合があり ${ }^{9 \sim 11)}$ ，顎骨骨 髄炎を顎骨の fibro-osseous lesion に含めて分類してい る者もある ${ }^{12,13)}$ ，筆者らは，骨㭪道炎のごとく炎症性疾患 であることが明確であるものは，fibro-osseous lesion

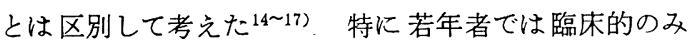
ならず病理組織学的にも，化骨性線維腫, 線維性骨巽形 成症との鑑別が困難な場合がある。その鑑別点として， 不規則な新生骨の增生と既存層板骨の肥厚, 不規則な改 造線のある層板骨, 膿瘍や腐骨の存在, 骨髄は柾な線維 性結合組織によって置換され多少とも炎症性細胞浸潤が みられる，等があげられている12,13).

Jacobsson ${ }^{18)}$ は下顎骨の慢性硬化性骨髄炎を組織学的 に4つの型に分類して扣り（I．密な骨硬化像，II．粗 な骨梁と壊死巣, III. 骨芽細胞の配列を伴ら細骨梁,

IV. 巨細胞を含む肉芽組織), これらの各型は互いに混 在すると述べている、筆者らの症例（症例 2,3 ）でも 組織像は一様ではなく，種々の割合で肉芽組織，骨新生 像，骨硬化像の混在がみられた。

また，長期に及んだ症例では，組織像が推移すること があり，全経過の把握が彮断に重要であると思われた。
結

語

小昌の慢性顎骨骨䯣炎の自騟例 4 例について病理学的 に検討を加光，以下の結論を得た。

1. 3 例は下顎に，1例は上頢に 発症しており，いず れも比較的広籁囲に及んでいた。

2. 上顎の 1 例は, 初期には典型的な慢性化膿性骨髄 炎の像を呈したが, 経過とともに化骨性線維腫に類似す る像を呈するに至った。

3. 下顎の 3 例中の 2 例は, 慢性び漫性硬化性骨䯣炎 に相当するものであった。 残る下頧の 1 例は Garré 氏 骨髄炎（化骨性骨膜炎）の䇛畹に含まれるものと思われ た。

4. 病理組織像は変化に富んでおり, 材料の採取部位 および時期により種々の像を呈するので，診断にあたっ ては全体像を把握することが重要であると思われた。

\section{引用文 献}

1）石川梧朗監修：口腔病理学 II. 改訂版, 永末苦 店, 京都, 1982，321-328貢。

2) Shafer, W.G., Hine, M.K., et al.: A Textbook of Oral Pathology. 4th ed., W.B. Saunders Co, Philadelphia, 1983, p 498-508.

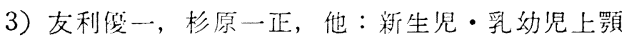
骨骨㭪炎の 3 例。日口外誌 29: 117-122 1983.

4) Rowe, N.L. and Heslop, I.H.: Periostitis and osteomyelitis of the mandible in childhood. Br. Dent J 6: 67-78 1957.

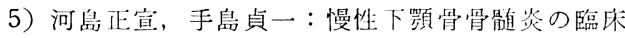
的観察。第 2 紼 いわ放 ついて。 日外誌 24: 316-324 1978.

6) Eversole, L.R., Leider A.S., et al.: Proliferative periostitis of Garré: its differentiation from other neoperiostoses. J Oral Surg 37: 7257311979.

7) Pindborg, J.J. and Kramer, I.R.H.: International histological classification of tumours. No. 5, Histological Typing of Odontogenic Tumors, Jaw Cysts, and Allied Lesions. WHO, Geneva, 1971, p 36-37.

8）浅田洸一：び漫性硬化性䫇骨骨䯣炎に関子る臨 床的・病理組織学的研究。 口病誌 45:334-363 1978.

9) Waldron, C.A., Giansanti, J.S., et al.: Sclerotic cemental masses of the jaws (so-called chronic sclerosing osteomyelitis, sclerosing osteitis, multiple enostosis, and gigantiform cementoma). Oral Surg 39: 590-604 1975.

10) Melrose, R., Abrams, A.M., et al.: Florid osseous dysplasia. A clinical-pathologic study of thirty-four cases. Oral Surg. 41: 62-82 
1976.

11) Jacobsson, S., Hallén, O., et al.: Fibro-osseous lesion of the mandible mimicking chronic osteomyelitis. Oral Surg 40: 433-444 1975.

12) Schmaman A., Smith I. et al.: Benign fibroosseous lesions of the mandible and maxilla. A review of 35 cases. Cancer 26: 303-312 1970.

13）牛込新一郎, 田所 衛, 他: 頭蓋・顎骨の非㳡 原性 Fibro-osseous lesion の組織診断と爁別. 聖マリアンナ医大誌 5：483-492 1977.

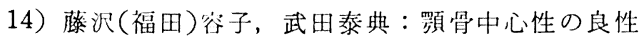
線維性ならびに線維骨性病変に関する病理学的 検討。第 1 報 症例の概要について。岩医大㳡 誌 7：131-138 1982.

15）藤沢(福田)容子, 武田泰典, 他：顎骨中心性の
良性線維性ならびに楾維骨性病変に関する病理 学的検討。第 2 報 多発性セメント質腫. 口科 誌 32: 117-130 1983.

16）藤沢（福田）容子, 武田泰典, 他：顎骨中心性 の良性線維性ならびに線維骨性病変に関する病 理学的檢討。第 3 報 根尖性セメント質異形成 症の成熟像と考えた病変について。口科誌 32 : 318-327 1983.

17）藤沢(福田)容子, 戸塚盛雄, 他：顎骨中心性の 良性線維性ならびに線䧽骨性病変に関する病理 学的檢討. 第 4 報 線維性病変. 岩医大阥誌 8: 187-195 1983.

18) Jacobsson, S. and Heyden, G.. Chronic sclerosing osteomyelitis of the mandible. Histologic and histochemical findings. Oral Surg 43: 357-364 1977. 